dr Ana Jovičić Vuković

Visoka poslovna škola strukovnih studija,

\section{Novi Sad}

\section{dr Snježana Gagić}

Visoka škola za menadžment i poslovne

komunikacije, Sremski Karlovci

UDK 338.486.3:640.412

005.591.6:334.7

\section{Ispravka: Inovacije $\mathbf{u}$ hotelijerstvu $(2017,19$, str. 27-35)}

U ovoj ispravci koriguje se izostanak autocitata doktorske disertacije Ane Jovičić. Greška je nastala omaškom u obradi teksta od strane autora i mišljenja autora da parafraziranje sopstvene doktorske disertacije nije neophodno i da je objavljivanje dela doktorske disertacije naučno prihvatljivo. Zahvaljujemo se Centru za evaluaciju u obrazovanju i nauci (CEON) na pomoći pri otkrivanju grešaka.

$\mathrm{U}$ deo Literatura, pod rednim brojem 17., dodaje se referenca:

Jovičić, A. Organizacioni faktori kao prediktori inovativnosti u hotelijerstvu Srbije, doktorska disertacija, Univerzitet u Novom Sadu, Prirodno-matematički fakultet, Novi Sad, 2015.

Kao poseban deo, na kraju rada, dodaje se Zahvalnost:

Delovi rada prezentovani su u doktorskoj disertaciji Jovičič Ane.
Uređivački odbor

\section{Opoziv: Standard hazard analysis, critical control point and hotel management $(2017,19$, str. 45-49)}

Odlukom Uredništva časopisa Turističko poslovanje, članak pod nazivom „Standard hazard analysis, critical control point and hotel management", autora: Vesne Vujačić, Grete Krešić, Saše Sušića i Marije Bodrože Solarov, koji je objavljen u broju 19/2017, opoziva se zbog autoplagijarizma. 